\title{
Changes in Intracellular pH Associated with Glutamate Excitotoxicity
}

\author{
Zoë Hartley ${ }^{1,2}$ and Janet M. Dubinsky ${ }^{1}$ \\ 'Department of Physiology, University of Texas Health Science Center, San Antonio, Texas 78284-7756 and ${ }^{2}$ Emory \\ University, Atlanta, Georgia 30322
}

\begin{abstract}
Excitotoxic neuronal injury is known to be associated with increases in cytosolic calcium ion concentrations. However, it is not known if perturbations in other intracellular ions are also associated with glutamate (GLU)-induced neuronal death. Accordingly, intracellular hydrogen ion concentrations were measured in cultured hippocampal neurons with the fluorescent dye BCECF during and after toxic exposures. Five minute GLU applications produced an initial cytosolic acidification. During the hour after GLU removal, intracellular $\mathrm{pH}\left(\mathrm{pH}_{i}\right)$ recovered steadily, resulting in a rebound cytosolic alkalinization. Lowering extracellular calcium depressed the initial GLU-induced acidification, suggesting that the rapid acidification may result partly as a consequence of calcium entry. An acidification-induced rebound alkalinization appeared to be activated by GLU exposure. Inhibitors of intracellular $\mathrm{pH}$ regulation, harmaline, 4,4'-diisothiocyanatostilbene-2,2'-disulfonic acid (DIDS), and replacement of external $\mathrm{Na}^{+}$with $\mathrm{N}$-methyl-glucamine ${ }^{+}\left(\mathrm{NMG}^{+}\right)$, retarded the rate of recovery from GLU-induced acidification. The rapid acidification and rebound alkalinization could be mimicked by challenging neurons with elevated external $\mathrm{K}^{+}$or replacement of external $\mathrm{Na}^{+}$with $\mathrm{NMG}^{+}$. Two or more hours following toxic GLU exposure, hydrogen ion concentration did not stabilize at initial levels but progressively increased. High $\mathrm{K}^{+}$ or $\mathrm{Na}^{+}$removal did not produce this long-term acidification and were not toxic. The cumulative increase in intracellular hydrogen ion may reflect the declining health of injured neurons and could contribute directly to neuronal death. Therefore, cytosolic acidification may act synergistically with increases in calcium concentration in mediating excitotoxicity.

[Key words: excitotoxicity, neurotoxicity, intracellular pH, glutamate, excitatory amino acids, hydrogen ion concentration, BCECF]
\end{abstract}

Delayed glutamate (GLU) excitotoxicity is thought to occur through a number of calcium-mediated events. Entry of calcium through both NMDA and non-NMDA ionotropic GLU channels (MacDermott and Dale, 1987; Murphy et al., 1987; Glaum et al., 1990; Iino et al., 1990; Gilbertson et al., 1991) has been

\footnotetext{
Received Jan. 14, 1993; revised Apr. 29, 1993; accepted May 6, 1993.

We thank Drs. Michael Barish, Edward J. Masoro, and Charles Levinson for insightful discussions, Dr. Barish for critical reading of the manuscript, Dr. Cheng Yuan for statistical analysis, and Ms. Marta Fournier for preparation of the cultures. Z.H. was a fellow of the Summer Undergraduate Research Fellowship program at UTHSCSA for 1992. This work was supported by NIH Grant $\Lambda$ G 10034

Correspondence should be addressed to Janet M. Dubinsky, Ph.D., Department of Physiology, University of Texas Health Science Center, 7703 Floyd Curl Drive, San Antonio, TX 78284-7756.

Copyright (C) 1993 Society for Neuroscience $0270-6474 / 93 / 134690-10 \$ 05.00 / 0$
}

postulated to activate calcium-dependent kinases, phosphatases, phospholipases, and endonucleases that eventually destabilize intracellular homeostasis and lead to neuronal damage and death (Orrenius et al., 1988; Choi, 1990). While GLU application was originally reported to produce sustained rises in $\left[\mathrm{Ca}^{2+}\right]_{i}$ (Connor et al., 1988; Ogura et al., 1988; Manev et al., 1989; Wahl et al., 1989; De Erausquin et al., 1990; Glaum et al., 1990; Ciardo and Meldolesi, 1991; Dubinsky and Rothman, 1991), recent experiments have described complete recovery of basal $\left[\mathrm{Ca}^{2+}\right]_{i}$ for clearly toxic GLU exposures (Randall and Thaycr, 1992; Dubinsky, 1993b). Thus, calcium-mediated processes associated with neuronal death must be activated in the hour or so following GLU overstimulation. This view is consistent with the observation that removal of extracellular calcium is protective against GLU-induced toxicity (Choi et al., 1987; Rothman et al., 1987).

However, other experiments have questioned the sole involvement of calcium, since neuronal death can occur without large deviations in $\left[\mathrm{Ca}^{2+}\right]_{i}$ and high potassium or cyanide induced increases in $\left[\mathrm{Ca}^{2+}\right]_{i}$ do not produce toxicity (Michaels and Rothman, 1990; Dubinsky and Rothman, 1991). Intracellular acidification has been postulated to contribute to ischemic neuronal death (Tombaugh and Sapolsky, 1990; Nedergaard et al., 1991; see Siesjo, 1992, for review). Previous calculations suggested that ischemia-induced shifts in whole brain $\mathrm{pH}$ could be accounted for by the changes within glial cells (Kraig et al., 1986). Neurotransmitter-induced variations in astroglial $\mathrm{pH}_{i}$ and brain extracellular $\mathrm{pH}$ have been documented extensively (Chesler and Chan, 1988; Jarolimek et al., 1989; Kraig and Chesler, 1990; Chesler and Rice, 1991; Chen and Chesler, 1992a; Chesler and Kaila, 1992). Reexamination of the relationship between changes in lactate accumulation and extracellular $\mathrm{pH}$ during ischemia has challenged the notion that the hydrogen ion distribution differs between glial and neuronal compartments (Katsura et al., 1991). Thus, internal neuronal pH disturbances could possible accompany excitotoxicity. Indeed, measurements with $\mathrm{H}^{+}$-sensitive microelectrodes have demonstrated that GLU and GABA application can directly acidify frog motoneurons and crayfish stretch receptor neurons, respectively (Enders et al., 1986; Kaila et al., 1992). Moreover, physiological levels of GLU produced parallel increases in $\left[\mathrm{H}^{+}\right]_{i}$ and $\left[\mathrm{Ca}^{2+}\right]_{i}$ among hippocampal neurons, suggestive of a synergistic contribution to excitotoxic neuronal death (Koch and Barish, 1991).

Since extended periods of elevated $\left[\mathrm{H}^{+}\right]_{i}$ have been demonstrated to be neurotoxic in vitro (Nedergaard et al., 1991), we have examined GLU-induced changes in $\mathrm{pH}_{i}$ among cultured hippocampal neurons with the hydrogen ion-sensitive dye $2^{\prime}, 7^{\prime}-$ bis-(2-carboxyethyl)-5-(and-6)carboxyfluorescein (BCECF). These experiments were designed to parallel those previously 
reported for $\left[\mathrm{Ca}^{2+}\right]_{i}$ on hoth short and long time scales (Dubinsky, 1993b).

\section{Materials and Methods}

Tissue culture. Hippocampal cultures from postnatal day 1 rat pups (Sprague-Dawley, Harlan) were prepared according to established procedures (Dubinsky, 1989, 1993b; Yamada et al., 1989). Neurons were plated onto a preplated astroglial feeder layer on polylysine- and collagen-coated, glass-bottomed, $35 \mathrm{~mm}$ petri dishes ( $\mathrm{pH}$ measurements) or plastic petri dishes (toxicity measurements) at a density of 500,000 cells per dish. Cultures were maintaincd in minimum cssential medium without glutamine containing $27.75 \mathrm{~mm}$ glucose, $10 \%$ NuSerum (Collaborative Research), $50 \mathrm{U} / \mathrm{ml}$ penicillin, and $50 \mu \mathrm{g} / \mathrm{ml}$ streptomycin, $335 \mathrm{mOsm}$ at $37^{\circ} \mathrm{C}$ in a humidified atmosphere containing $5 \% \mathrm{CO}_{2}$ for $12-18 \mathrm{~d}$ before use.

Intracellular $p H$ measurements. Intracellular hydrogen ion concentration $\left(\left[\mathrm{H}^{+}\right]_{i}\right)$ was assessed with ratio measurements of the hydrogen ion-sensitive dye BCECF. Cultures were loaded with the dye by incubation of a $4 \mu_{\mathrm{M}}$ concentration of the acetoxymethyl ester form (BCECFAM; lot 1114, Molecular Probes) for $5 \mathrm{~min}$ in the growing medium at $37^{\circ} \mathrm{C}$. BCECF loading was terminated by subsequent rinsing with a basic salt solution containing (mM) $139 \mathrm{NaCl}, 3 \mathrm{KCl}, 1.8 \mathrm{CaCl}_{2}, 0.8 \mathrm{MgSO}_{4}$, $1.0 \mathrm{NaHCO}_{3}, 27.75$ glucose, 15 sucrose, $10 \mathrm{Na}$-HEPES, and 0.01 glycine, $329 \mathrm{mOsm}, \mathrm{pH} 7.3$ at $37^{\circ} \mathrm{C}$, and cultures were placed on the heated stage of an Olympus IMT-2 invertcd microscope for 15-20 min prior to data acquisition. In some experiments, $\mathrm{CaCl}_{2}$ was increased to 10 mm or omitted altogether. In experiments assessing $\mathrm{pH}_{i}$ many hours after GLU exposure, cultures were initially rinsed with Earle's Balanced Salt Solution (EBSS+) containing (mM) $116 \mathrm{NaCl}, 5.4 \mathrm{KCl}, 1.8 \mathrm{CaCl}_{2}$ $0.1 \mathrm{MgSO}_{4}, 0.9 \mathrm{NaH}_{2} \mathrm{PO}_{4}, 26.2 \mathrm{NaHCO}_{3}, 27.75$ glucose, 35 sucrose, 0.01 glycine, and phenol red, $328 \mathrm{mOsm}$, and exposed to $500 \mu \mathrm{M}$ GLU for $5 \mathrm{~min}$ at $37^{\circ} \mathrm{C}$ in $95 \%$ air, $5 \% \mathrm{CO}_{2}$. Cultures were rinsed in fresh EBSS + and returned to the incubator for variable periods of time; 4 $\mu \mathrm{M}$ BCECF-AM was subsequently added to the EBSS + for 5 min prior to fluorescence measurements.

Responses of individual neurons at $35^{\circ} \mathrm{C}$ to $500 \mu \mathrm{M}$ GLU application were monitored by intermittent ratio imaging following delivery of a concentrated stock solution of GLU to the edge of the dish accompanied by gentle mixing. After 5 min of GLU cxposurc, the dishes were manually rinsed three times with warmed balanced salt solution. This method of application mimics the procedures used in previously published calcium measurement and toxicity experiments (Dubinsky, 1993b). 4,4'Diisothiocyanatostilbene-2,2'-disulfonic acid (DIDS; Sigma) and harmaline (Sigma) were prepared as $100 \times$ stock solutions in basic salt solution and added similarly for final concentrations of $100 \mu \mathrm{M}$. The $\mathrm{pH}$ of the external solution at the beginning and end of the experiments remained consistent at 7.3 .

Ratio measurements were calculated from digitized images of emitted BCECF fluorescence (520-555 nm; dichroic cutoff, $515 \mathrm{~nm}$ ) for excitation at 495 and $440 \mathrm{~nm}$ from a $75 \mathrm{~W}$ xenon source through a $5 \%$ transmittance neutral density filter. A Nikon CF Fluor $40 \times$ oil 1.3 NA objective was used to capture the fluorescence in conjunction with a DAGE-MTI GenIIsis Image Intensificr and CCD-72 camera. Fields for imaging were selected under bright-field illumination prior to any fluorescence measurements and contained nonclumped, healthy, intact neurons.

Calibrations were performed on individual neurons from separate cultures incubated in nigericin containing solutions of known pH (Thomas et al., 1979). Specifically, these solutions contained (mM) $150 \mathrm{KCl}$, $1.8 \mathrm{CaCl}_{2}, 0.8 \mathrm{MgCl}_{2}, 10 \mu \mathrm{g} / \mathrm{ml}$ nigericin (Molecular Probes), and 10 mM concentrations of $2-[N$-morpholino]ethanesulfonic acid $(\mathrm{pH} 5.6$, 6.2), (3-[ $N$-morpholino]propanesulfonic acid $(\mathrm{pH} 6.6,7.1)$, or HEPES (pH 7.4, 7.85, 8.2). The resulting relationship between ratio values and $\mathrm{pH}_{i}$ was fitted with the sigmoidal curve; ratio $=\min +\left[\mathrm{max} /\left(1+\left(10^{\mathrm{pH}} /\right.\right.\right.$ $\left.\left.10^{\text {mid }}\right)^{\text {slope }}\right)$, where $\min =1.72, \max =9.71, \operatorname{mid}=6.97$, and slope $=$ 0.958 . The midpoint of the curve (mid) corresponded to the $\mathrm{pH}$ value for half-maximal BCECF sensitivity. The calculated value agreed well with the $\mathrm{pK}^{\prime}$ value published for BCECF of 6.97 determined by more rigorous calibration procedures (James-Kracke, 1992). Harmaline contributed an additional fluorescence signal at $440 \mathrm{~nm}$ that sometimes affected measurements obtained at very high gains. Accordingly, calibration values in harmaline were probably different and hence no $\mathrm{pH}_{i}$ equivalences are provided. All changes reported for ratio values in harmaline were observed in the $495 \mathrm{~nm}$ values and were not attributable to harmaline autofluorescence. Calibration values were not changed by the addition of DIDS.

To prevent both bleaching of the dye and phototoxic damage to the neurons, measurements were made intermittently at intervals greater than or equal to $60 \mathrm{sec}$. In addition, no attempt was made to calculate the internal neuronal buffering capacity for $\mathrm{H}^{+}$. Therefore, we were unable to calculate $\mathrm{II}^{+}$flux rates. In order to comparc the rates of recovery from internal acidification under different experimental conditions, an empirical measure of the rate of rise of the ratio values (in ratio units/min) was tabulated from all data points collected following removal of the acid-loading agent.

All statistics were performed on ratio values. For the GLU response curves, distinctions between significance levels below $p<0.05$ have been omitted for graphical clarity.

Toxicity experiments. Neuronal survival was assessed by counting neurons containing and excluding trypan blue $24 \mathrm{hr}$ following exposure to various test solutions as previously described (Dubinsky, 1993b). Briefly, growing medium was replaced with EBSS+ and $500 \mu \mathrm{M}$ GLU was added from a concentrated stock solution. After a 5 min incubation at $37^{\circ} \mathrm{C}$ in $5 \% \mathrm{CO}_{2}$, cultures were rinsed in fresh EBSS + and incubated overnight. For the ion substitution experiments, EBSS-like solutions containing $50 \mathrm{~mm} \mathrm{~K}{ }^{+}$substituted for $\mathrm{Na}^{+}$or $145 \mathrm{~mm} \mathrm{~N}$-methyl-glucamine $+\left(\mathrm{NMG}^{+}\right)$substituted for $\mathrm{Na}^{+}$were added instead of EBSS+ during the $5 \mathrm{~min}$ exposure. Similar ion substitutions were made in the balanced salt solution used for the $\mathrm{pH}_{i}$ experiments.

\section{Results}

\section{Short-term $G L U$-induced changes in intracellular $p H$}

Initial BCECF ratio measurements in untreated cultures bathed in HEPES-buffered basic salt solution were $5.77 \pm 0.24$ (mean $\pm \mathrm{SEM}, N=28$ neurons from four experiments), corresponding to $\mathrm{a}_{i}$ of $7.00 \pm 0.05$ or an intracellular hydrogen ion concentration $\left(\left[\mathrm{H}^{+}\right]_{i}\right)$ of $100 \mathrm{~nm}$. Similar values for neuronal $\mathbf{p H}_{i}$ in HEPES-buffered media have been reported previously (Nachshen and Drapeau, 1988; Koch and Barish, 1991; Raley-Susman et al., 1991). Following the establishment of a stable resting $\mathrm{pH}_{i}$, ratios were obtained intermittently during a 5 min bath application of $500 \mu \mathrm{M}$ GLU (Fig. $1 A$ ). Immediately upon introduction of GLU, fluorescence ratios fell rapidly, indicating an intracellular acidification. In four experiments, the average minimum ratio value attained in the presence of GLU was $3.68 \pm$ 0.07 , corresponding to a $\mathrm{pII}_{i}$ of $6.48 \pm 0.02$, or $331 \mathrm{nM}\left[\mathrm{H}^{+}\right]_{i}$. After several minutes in the continued presence of GLU, ratios began to creep upward, suggesting the onset of a recovery process.

Upon removal of the GLU, ratio values recovered initial levels and continued to climb, indicating an intracellular alkalinization. The rate of recovery was slow compared to the initial drop and varied between culture dishes. Thirty to sixty minutes were generally required to regain and surpass initial $\mathrm{pH}_{i}$ levels. A secondary alkalinization was observed at $60 \mathrm{~min}$ in 27 out of 28 neurons from four experiments. Since the ratios were continuing to increase at the end of the measurement period, maximum levels for the alkalosis could not be established. No changes in basal $\mathrm{pH}_{i}$ were observed when control solution changes were performed with basic salt solution (Fig. $1 B$ ).

GLU toxicity has principally been associated with an influx of extraccllular calcium. Therefore, GLU induced changes in $\mathrm{pH}_{i}$ were monitored in cultures incubated in extracellular solutions with either no added calcium or $10 \mathrm{~mm}$ calcium, conditions that should alter the influx of calcium. Nominally "calcium-free" solution should minimize and the high external calcium solution should augment the GLU-induced increase in intracellular calcium concentration $\left(\left[\mathrm{Ca}^{2+}\right]_{i}\right)$, respectively. If GLU-induced $\left[\mathrm{H}^{+}\right]_{i}$ changes were linked to $\left[\mathrm{Ca}^{2+}\right]_{i}$ changes, then these solutions might be expected similarly to minimize or aug- 

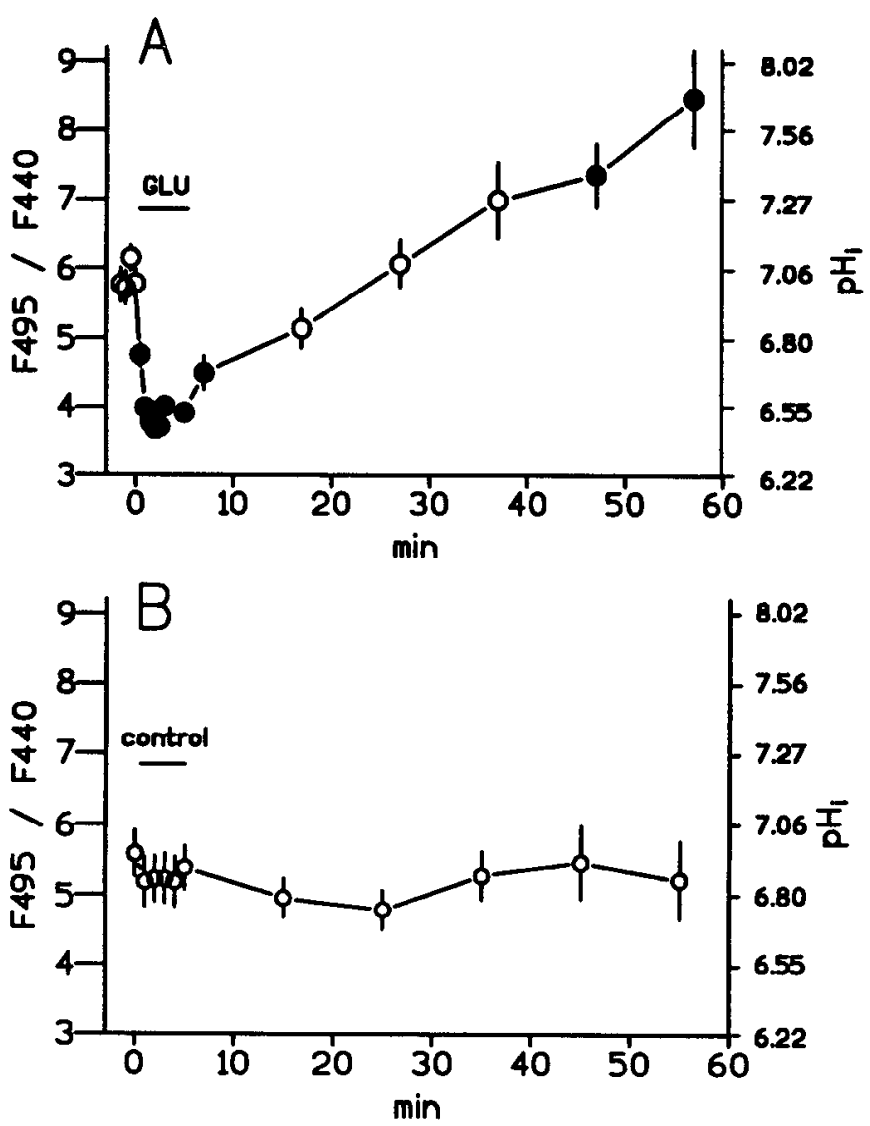

Figure 1. Hippocampal neurons responded to $500 \mu \mathrm{M}$ GLU exposure $(A)$ with an initial acidification followed by a rebound alkalinization. Data points represent mean ratio values $( \pm$ SEM) for 27 neurons from three separate experiments. $B$, Intracellular $\mathrm{pH}$ remained unaltered during control solution changes. In each curve, solid symbols represent data points significantly different from the initial value at 0 min (Dunnett's test, $p<0.05$ ). Data are from four neurons in one of two replicate experiments.

ment the observed changes in BCECF fluorescence. In lowered external calcium solution the basal $\mathrm{pH}_{i}$ was higher and the initial fall in $\mathrm{pH}_{i}$ occurred more slowly and was not as prominent (Fig. $2 A$ ). Subsequently, the recovery of basal levels and secondary increase in $\mathrm{pH}_{i}$ appeared delayed in onset and overall time course. Elevated external calcium did not alter the initial $\mathrm{pH}_{4}$ decrease appreciably, but the recovery phase occurred more rapidly. The steady state rate of recovery from acidification was only slightly retarded by the nominally "calcium-free" condition (Table 1). Other manipulations of external calcium failed to produce any changes in the rates of recovery (Table 1).

To manipulate $\left[\mathrm{Ca}^{2+}\right]_{i}$ further, cultures were preincubated for an hour in $4 \mu \mathrm{M}$ BAPTA-AM, a cell-permeant calcium chelator. BAPTA-AM was expected to blunt and prolong the initial increase in $\left[\mathrm{Ca}^{2+}\right]_{i}$ but not to prevent it (Dubinsky, 1993a). Incubation with BAPTA-AM did not significantly alter the basal ratio values $(5.49 \pm 0.21, N=22$ from three experiments, corresponding to $\mathrm{pH}_{i}$ of $\left.6.94 \pm 0.04,\left[\mathrm{H}^{+}\right]=115 \mathrm{nM}\right)$. As with the lowered external calcium condition, BAPTA-AM-treated neurons responded to GLU with a slower, less prominent initial acidification and a delayed onset of recovery and secondary alkalinization (Fig. $2 B$ ). In general, though, BAPTA-AM treatment was not as effective as removal of external calcium in altering the changes in $\mathrm{pH}_{i}$. Thus, GLU-induced changes in $\left[\mathrm{H}^{+}\right]_{i}$
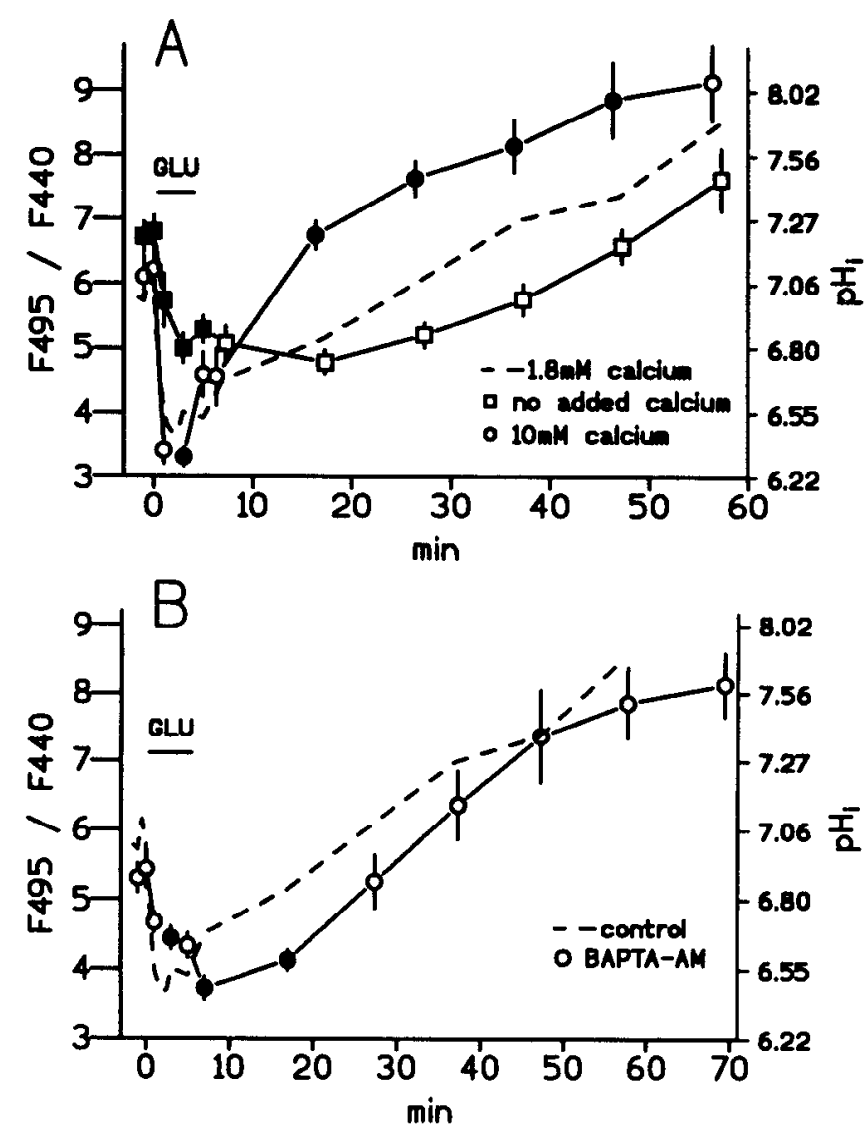

Figure 2. Manipulations of calcium availability altered the extent of $\mathrm{pH}_{i}$ changes in response to GLU. $A$, Lowering extracellular calcium muted the initial acidification and delayed the rebound alkalinization. Raising extracellular calcium speeded the onset of alkalinization. $B$, Introduction of the cell-permeant calcium chelator BAPTA-AM slowed the initial acidification and delayed the rebound alkalinization. Solid symbols in $A$ and $B$ represent data points differing from the coincident time points in the GLU response in normal calcium (Fig. $1 A$; represented by dashed line; $p<0.05$, ANOVA followed by Student-Newman-Keuls test). In all curves, data points during the GLU-induced acidification were significantly lower than ratios at $0 \min (p<0.05$, Dunnett's test). Ratios were significantly more alkaline after $30 \mathrm{~min}$ in $10 \mathrm{~mm}$ calcium and after $40 \mathrm{~min}$ in BAPTA ( $p<0.05$, Dunnett's test). Data were combined from 16 or 17 neurons in three experiments in each condition.

appeared to be influenced by the concomitant alterations in $\left[\mathrm{Ca}^{2+}\right]_{i}$.

A prominent influx of $\mathrm{Na}^{+}$was also expected following GLU receptor activation. Since the $\mathrm{Na}^{+}-\mathrm{H}$ antiporter has been implicated in the regulation of $\mathrm{pH}_{i}$ in hippocampal neurons (RaleySusman et al., 1991), $\mathrm{Na}^{+}$fluxes or alterations in the $\mathrm{Na}$ gradient may have contributed to the observed $\mathrm{pH}_{i}$ changes. Slowed operation of the $\mathrm{Na}^{+}-\mathrm{H}^{+}$antiporter following $\mathrm{Na}^{+}$influx through GLU channels could have contributed to the GLU-induced fall in $\mathrm{pH}_{i}$, or activation of the antiporter could be responsible for the subsequent increase in $\mathrm{pH}_{i}$. Two different treatments were applied to test the involvement of the $\mathrm{Na}^{+}-\mathrm{H}^{+}$antiporter. Harmaline, a specific inhibitor of this pump in hippocampal tissue, human placental brush border membranes, and renal microvillus membranes (Aronson and Bounds, 1980; Balkovetz et al., 1986; Raley-Susman et al., 1991), was employed both during and after GLU exposure. Introduction of $100 \mu \mathrm{M}$ harmaline without rinsing produced an initial fall in BCECF fluorescence to a stable plateau (data not shown), indicating that the $\mathrm{Na}^{+}-$ 
Table 1. Steady state rates of recovery from the initial GLU-induced acidification

Experiment
GLU
No added calcium
10 mM External calcium
BAPTA-AM
Harmaline
DIDS
NMG $^{+}$in rinse
Delay after pretreatments
$0.5 \mathrm{hr}$
$1 \mathrm{hr}$
$2 \mathrm{hr}$
$4 \mathrm{hr}$
$6 \mathrm{hr}$
$8 \mathrm{hr}$
$12 \mathrm{hr}$

Recovery rate

For each neuron the rate of recovery was calculated as the slope of the linear regression line fit to all time points following GLU removal. Values are the mean \pm SEM of calculated slopes from all neurons $(N)$, in ratio units $/ \mathrm{min}$.

${ }^{*} p<0.05$, ANOVA followed by two-tailed $t$ test with Bonferroni correction compared to GLU.

${ }^{* *} p<0.01$.

$* * * p<0.001$.

$\mathrm{H}^{+}$antiporter was active at rest to remove $\mathrm{H}^{+}$. In the continued presence of harmaline, GLU still produced a further rapid fall in ratio values (Fig. $3 A$ ). The recovery from this additional acidification was significantly slowed in comparison to control solutions (Table 1) and recovery beyond initial levels was not observed within 60 min. When $\mathrm{Na}^{+}-\mathrm{H}^{+}$antiporter activity was blocked by $\mathrm{NMG}^{+}$substitution for external $\mathrm{Na}^{+}$either before or after GLU treatment, the recovery from acidification was also retarded (Fig. 3B, Table 1). Therefore, $\mathrm{Na}^{+}-\mathrm{H}^{+}$antiporter activity appeared to be involved in the recovery from the initial acidification and the rebound alkalinization. In addition, the $\mathrm{Na}$-dependent $\mathrm{Cl}-/ \mathrm{HCO}_{3}{ }^{-}$exchanger, also present within hippocampal neurons (Raley-Susman et al., 1991), contributed to the recovery from acidification since its inhibitor, DIDS (Boron et al., 1981), also slowed the recovery process when present throughout the $60 \mathrm{~min}$ observation period (Fig. $3 \mathrm{C}$, Table 1). In the continuous presence of DIDS alone, neuronal $\mathrm{pH}_{i}$ declined and then recovered to a slightly elevated level (data not shown).

\section{Other conditions producing short-term acidification}

Similar cellular acid-loading followed by a slow recovery and rebound alkalinization could be observed when hippocampal cultures were bathed in $50 \mathrm{~mm} \mathrm{~K}+$ for $5 \mathrm{~min}$. In the presence of elevated potassium, ratios in three dishes dropped to $4.39 \pm$ 0.15 or a $\mathrm{pH}_{i}$ of $6.68 \pm 0.04$ or $209 \mathrm{nM}\left[\mathrm{H}^{+}\right]_{i}(N=26$ neurons from three experiments; Fig. $4 A$ ). Removal of extracellular sodium and substitution of $\mathrm{NMG}^{+}$, a cation that is not a substrate for the $\mathrm{Na}^{+}-\mathrm{H}^{+}$antiporter, also produced an acidification among hippocampal neurons (Koch and Barish, 1991; Raley-Susman et al., 1991). In our experiments, $\mathrm{pH}_{i}$ declined during $\mathrm{Na}^{+}$removal and $\mathrm{NMG}^{+}$exposure to comparable levels (ratio of 4.43 $\pm 0.16, N=34$ neurons from three experiments, corresponding to $6.69 \pm 0.04 \mathrm{pH}_{i}, 204 \mathrm{nM}\left[\mathrm{H}^{+}\right]_{i}$ ) followed by a slow recovery and subsequent rebound increase in $\mathrm{pH}_{i}$ (Fig. $4 B$ ).
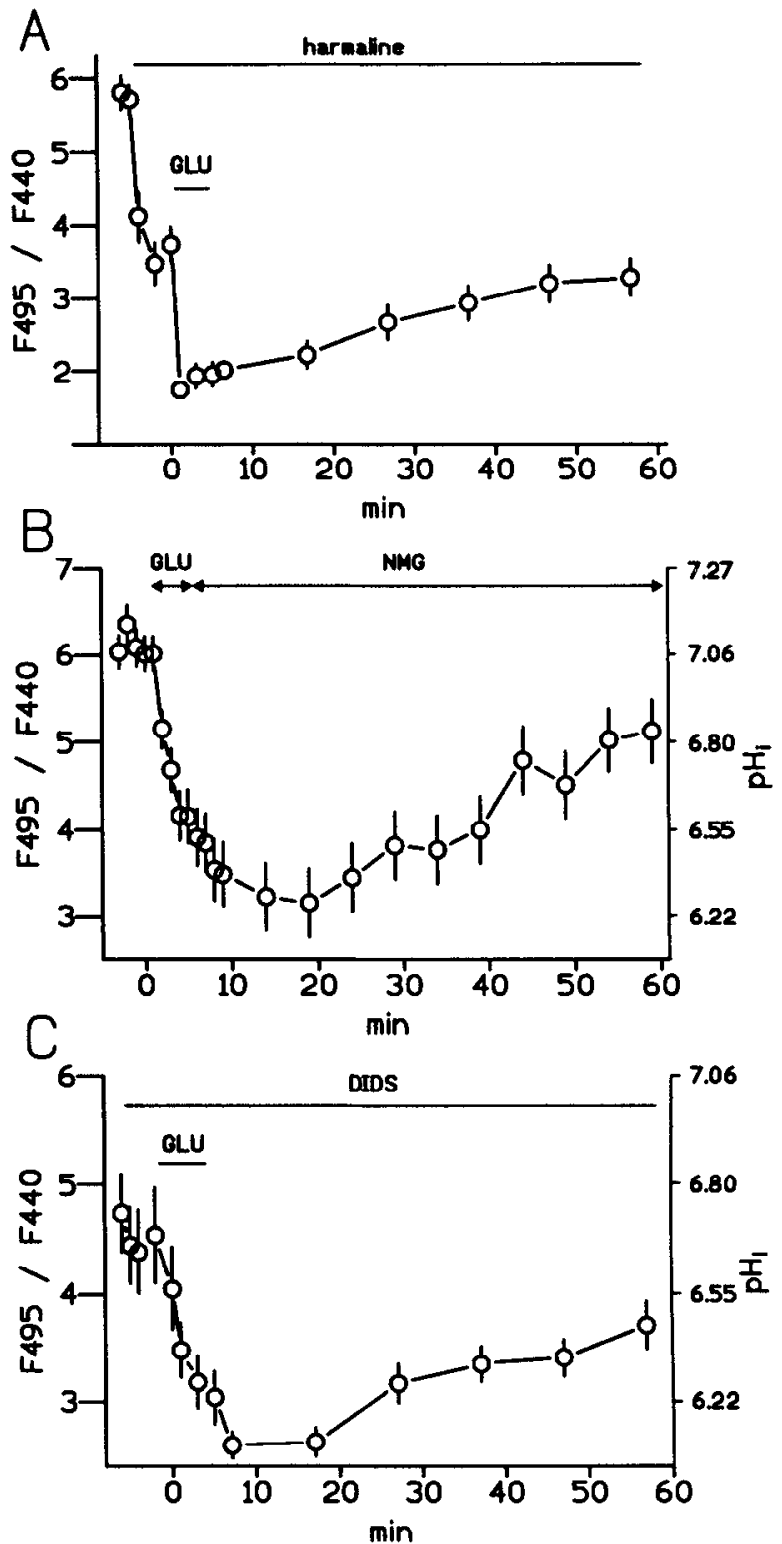

Figure 3. Inhibitors of hydrogen extrusion depressed the recovery from GLU-induced initial acidification. In the continuous presence of 100 $\mu \mathrm{M}$ harmaline $(A)$ or DIDS $(C)$, GLU produced an initial acidification with a slowed recovery. $B, \mathrm{NMG}^{+}$substitution for external $\mathrm{Na}^{+}$in the rinse produced a further acidification and retarded the subsequent recovery. Data represent 17-23 neurons from single experiments selected from two to four replicates.

\section{Long-term GLU-induced acidification}

The approximately $1 \mathrm{hr}$ observation period following BCECFAM loading was not sufficient to determine if the rebound alkalinization was severe enough to contribute to the eventual toxicity expected from this dose of GLU. To monitor $\mathrm{pH}_{i}$ changes during the hours following GLU exposure, cultures were pretreated with an equivalent exposure to GLU, rinsed, and incubated for variable periods of time prior to loading with BCECFAM. Initial ratio measurements in morphologically intact neurons at various times after GLU pretreatment revealed that $\mathrm{pH}_{i}$ remained elevated for about an hour, returning to basal levels

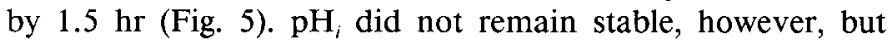
continued to fall over the next $10 \mathrm{hr}$. This progressive increase 

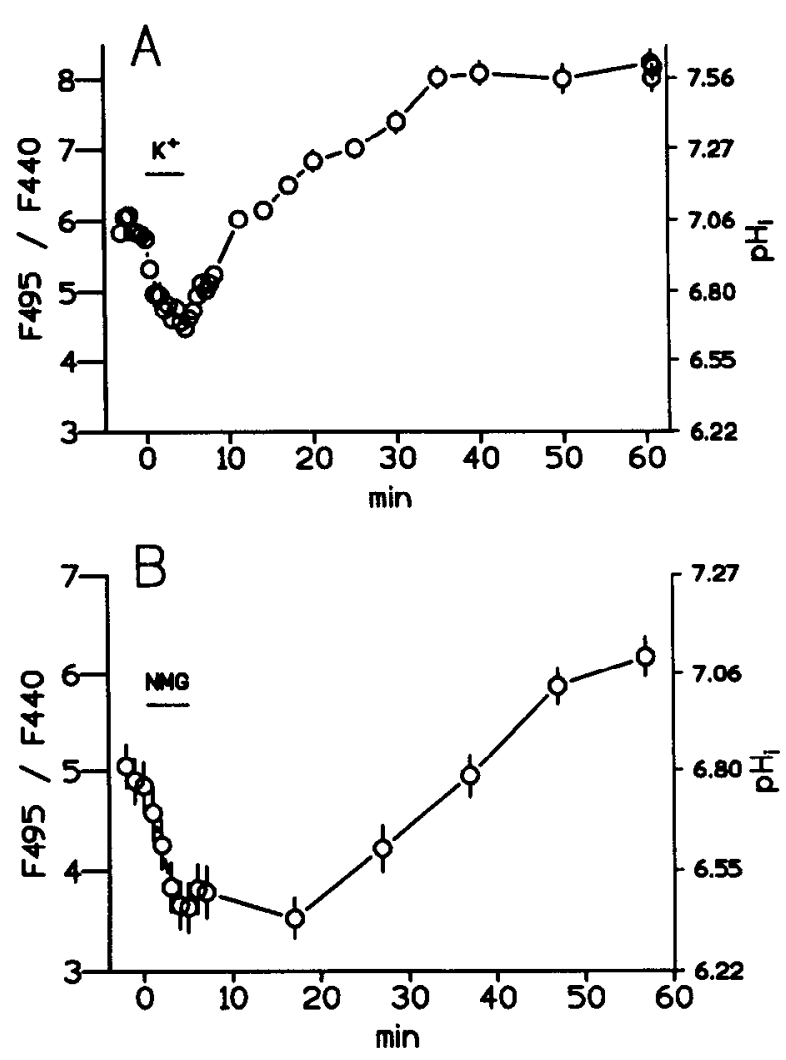

Figure 4. Short-term acidification and rebound alkalinization produced by $50 \mathrm{~mm}$ external potassium $(A)$ and $\mathrm{NMG}^{+}$substitution for external sodium $(B)$. Single representative experiments of seven or eight neurons each are illustrated from among three replicates.

in $\left[\mathrm{H}^{+}\right]_{i}$ constituted a third, long-term effect of GLU that reflected a clear loss of hydrogen ion homeostasis.

Other treatments (high external potassium and NMG substitution for sodium) that produced immediate acidification and the secondary rebound alkalinization did not result in a longterm acidification $12 \mathrm{hr}$ after exposure (Fig. 5). Hippocampal cultures exposed to elevated potassium concentration or $\mathrm{NMG}^{+}$ replacement of external $\mathrm{Na}^{+}$exhibited normal ratio values $\left(\mathrm{pH}_{i}\right.$ levels) after this prolonged interval. Similarly, control cultures receiving simple solution changes failed to show any deterioration in basal ratio values after $12 \mathrm{hr}$.

During this extended period after a toxic GLU exposure, hippocampal neurons retained their ability to respond to GLU both electrophysiologically and with an increase in $\left[\mathrm{Ca}^{2+}\right]_{i}$ (Dubinsky, 1993b). Therefore, cultures were tested to determine if the GLUinduced $\left[\mathrm{H}^{+}\right]$effects were also preserved despite the progressive decline in basal $\mathrm{pH}_{i}$. BCECF responses of hippocampal cultures to application of GLU at various times after a toxic pretreatment varied depending upon the $\mathrm{pH}_{i}$ level attained during the interval following pretreatment (Fig. 6). At short intervals of $0.5-1 \mathrm{hr}$, the rapid GLU-induced acid response was greatly attenuated or nonexistent (Fig. 6A). The absence of a response was notable during this period of rebound alkalinization following the pretreatment. A new, secondary increase in $\mathrm{pH}_{i}$ was difficult to distinguish from the continuously rising values produced by the GLU pretreatment. In the 2-6 hr interval following pretreatment, when $\mathrm{pH}_{i}$ was slightly depressed, GLU induced both the rapid acidification and subsequent recovery and alkalosis (Fig. $6 B$ ). Once $\mathrm{pH}_{i}$ had declined substantially, at 8 and $12 \mathrm{hr}$ after

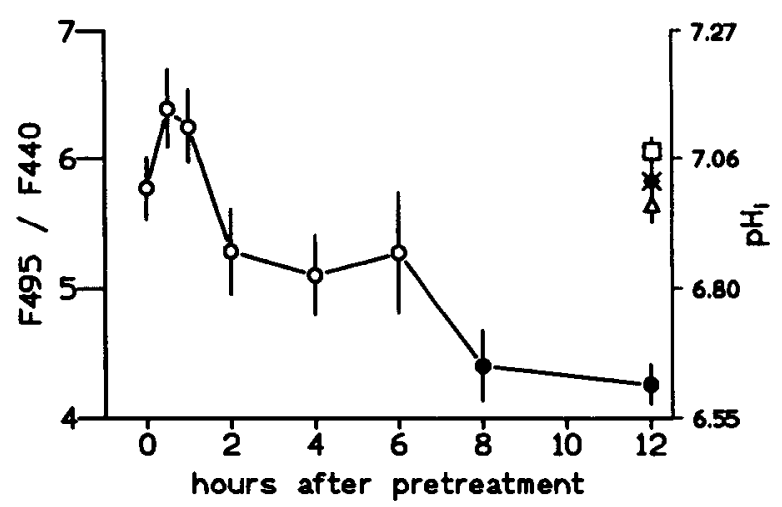

Figure 5. BCECF ratio measurements taken at long intervals after 5 min acidifying pretreatments. Neurons were pretreated with GLU and returned to the incubator for the indicated time prior to loading with BCECF (circles). Solid circles indicate ratio values significantly different from the initial ratios in naive cultures $(0 \mathrm{hr}$, no pretreatment; $p<0.05$, ANOVA followed by Dunnett's test). Other pretreatments failing to produce the decline in $\mathrm{pH}_{i}$ at $12 \mathrm{hr}$ were $500 \mu \mathrm{M}$ GLU plus $20 \mu \mathrm{M}$ CNQX and $20 \mu \mathrm{M} \mathrm{MK}-801$ (square), $50 \mathrm{~mm}$ external $\mathrm{K}^{+}$(diamond), and $\mathrm{NMG}^{+}$ substitution for external $\mathrm{Na}^{+}$(cross), and solution change controls (triangle). At $12 \mathrm{hr}$, only the GLU pretreatment was significantly different from the solution change controls $(p<0.05$, ANOVA followed by Dunnett's test). Data are combined initial measurements from three to five experiments (12-27 neurons) at each time point.

pretreatment, the rapid acidification was again muted but the secondary rise in $\mathrm{pH}_{i}$ was observed (Fig. $6 \mathrm{C}$ ). At all of these extended times, the steady state rate of recovery was substantially retarded compared to the rate observed upon single GLU exposure (Table 1). Deterioration of somal morphology could not account for the variability among responses since all imaged neurons appeared healthy. Thus, after toxic pretreatment, the GLU-induced initial decline in $\mathrm{pH}_{i}$ and the ensuing rate of recovery appeared labile and possibly dependent upon the existing $\left[\mathrm{H}^{+}\right]_{i}$ or $\left[\mathrm{Ca}^{2+}\right]_{i}$.

\section{GLU receptor antagonists block long-term acidification}

Antagonists of ionotropic GLU receptors, 6-cyano-7-dinitroquinoxaline-2,3-dione (CNQX) and MK-801, failed to block totally the GLU-induced initial acidification and secondary rebound alkalinization in the majority of neurons (Fig. $7 A$ ). The minimum ratio value attained in the presence of antagonists (4.22 $\pm 0.13, N=25$, corresponding to a $\mathrm{pH}_{i}$ of $6.63 \pm 0.03$ or $234 \mathrm{nM}\left[\mathrm{H}^{+}\right]_{i}$ ) reflected a significantly reduced accumulation of $\left[\mathrm{H}^{+}\right]_{i}$ compared to GLU alone $\left(\mathrm{pH}_{i}=6.48\right.$; see above; $p<$ 0.001 with two-tailed $t$ test). In only 3 out of 28 neurons tested in five experiments, CNQX and MK-801 were effective at preventing the initial decrease in $\mathrm{pH}_{i}($ Fig. $7 B$ ). In these three neurons, in the absence of the initial acid transient, no subsequent alkalosis was observed.

CNQX and MK-801 did, however, prevent the long-term acidification induced by toxic GLU exposure (Fig. 5). Twelve hours after a combined treatment with GIIU, CNQX, and MK801 , ratio values remained at levels comparable to initial baseline ratios, even though an initial acidification and rebound alkalinization probably occurred at the time of treatment.

\section{Toxicity associated with treatments producing acidification}

Hippocampal neuronal survival was assessed $24 \mathrm{hr}$ following the various treatments found to manipulate $\mathrm{pH}_{i}$ (Fig. 8). A 5 min treatment with $500 \mu \mathrm{M}$ GLU proved lethal, in agreement 

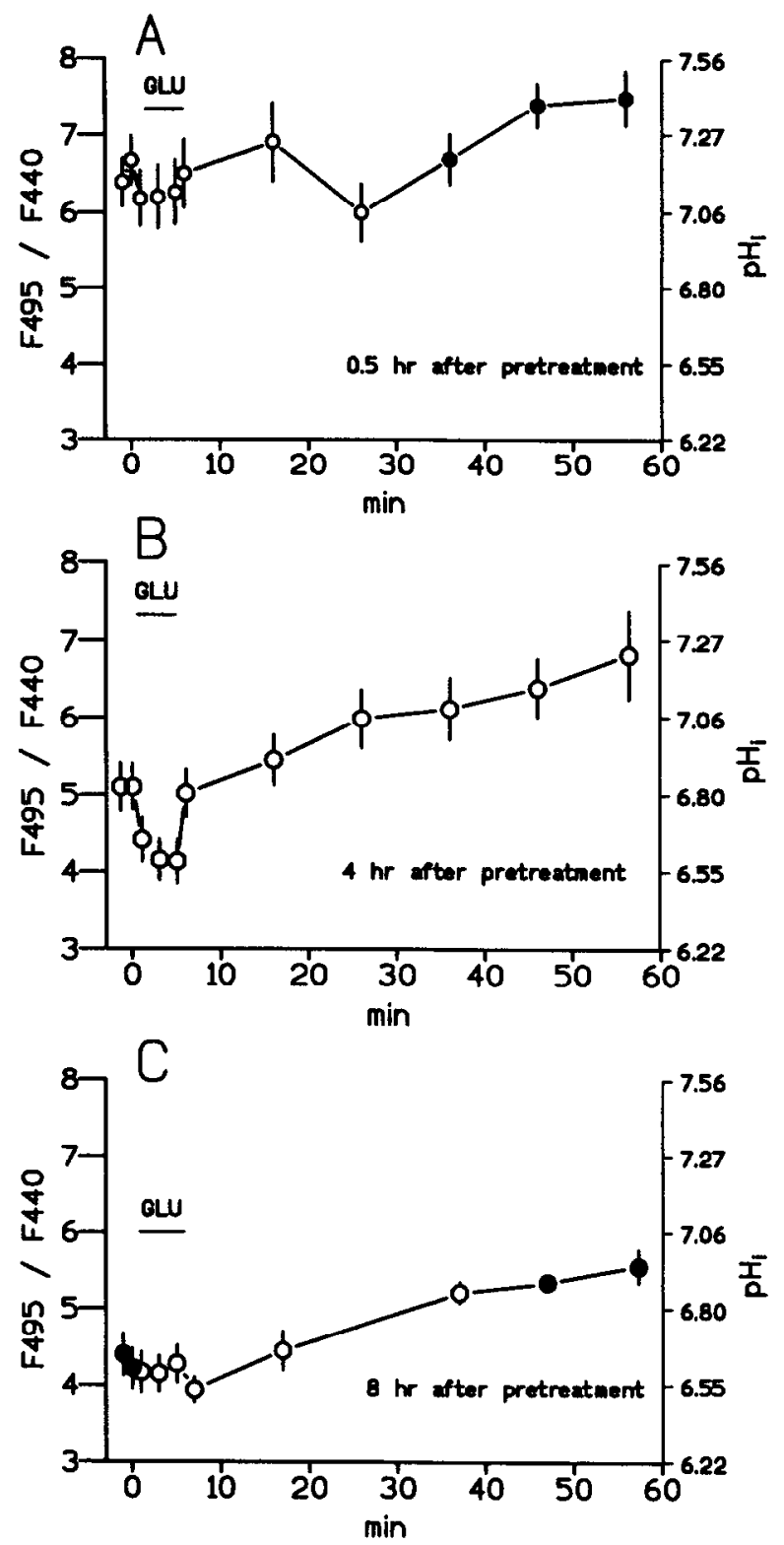

Figure 6. Response of hippocampal neurons to GLU at various times after a previous GLU pretreatment. $A$, Cultures were pretreated for 5 min with $500 \mu \mathrm{M}$ GLU, rinsed and incubated for $30 \mathrm{~min}$ prior to BCECFAM loading, and monitored during and after the 5 min test GLU exposure. Ratio values are not significantly different from initial levels over the course of an hour (Dunnett's test). $B$, Four hour interval between pretreatment and test exposure. Only the ratio at $57 \mathrm{~min}$ is significantly different from the initial value at $0 \min (p<0.05$, Dunnett's test). $C$, Eight hour interval between pretreatment and test exposure. Ratios beyond $30 \mathrm{~min}$ are significantly different from that at 0 min $(p$ $<0.05$, Dunnett's test). In all curves, solid symbols represent data points significantly different from corresponding points in the GLU response in normal calcium (dashed line from Fig. $1 A ; p<0.05$, ANOVA followed by Student-Newman-Keuls test). Traces represent averages of three experiments each (15-21 neurons).

with previous experiments (Michaels and Rothman, 1990; Dubinsky and Rothman, 1991). Ionotropic GLU receptor antagonists protected against excitotoxicity, as expected (Michaels and Rothman, 1990), despite their failure to prevent the initial decrease in $\mathrm{pH}_{i}$. Similarly, hippocampal neurons survived shortterm elevations in external $\mathrm{K}^{+}$or removal of external $\mathrm{Na}^{+}$. Thus, all treatments producing the initial acidification and re-
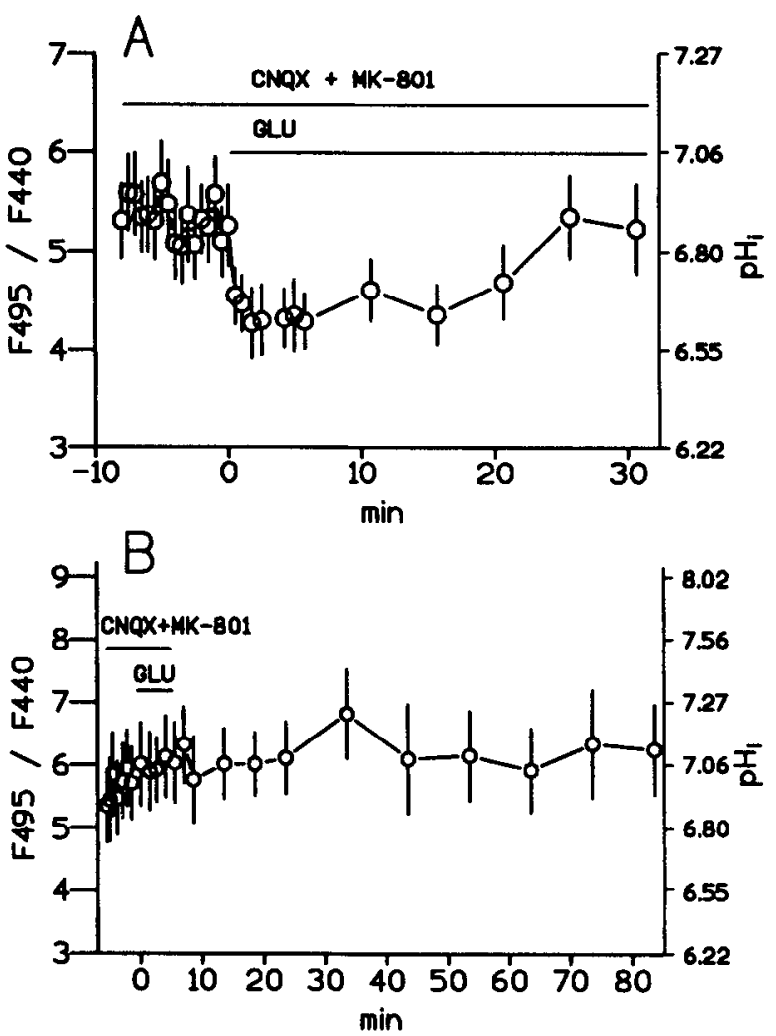

Figure 7. Short-term GLU-induced $\left[\mathrm{H}^{+}\right]_{i}$ responses were not prevented by the combination of $20 \mu \mathrm{M}$ CNQX and $20 \mu \mathrm{M}$ MK- 801 in the majority of neurons tested $(A)$. In a minority of neurons, ionotropic GLU antagonists prevented both the initial acidification and the subsequent rebound alkalinization $(B)$. Two out of six experiments (three or four neurons each) are illustrated.

bound alkalinization, but not the long-term decline in $\mathrm{pH}_{i}$, were not toxic. GLU exposure was notably the only treatment resulting in both the progressive, long-term decline in $\mathrm{pH}_{i}$ and ccll dcath.

\section{Discussion}

\section{Mechanisms of $G L U$-induced alterations in $p H_{\mathrm{i}}$}

Toxic exposure to GLU produced a continually varying pattern of changes in $\left[\mathrm{H}^{+}\right]_{i}$ among hippocampal neurons. Initially, during the GLU overstimulation, $\left[\mathrm{H}^{+}\right]_{i}$ increased rapidly to a peak value and began to recover. Secondarily, after removal of GLU, $\left[\mathrm{H}^{+}\right]_{i}$ steadily decreased, attaining and undershooting basal levels over the course of the next hour. Subsequently, $\left[\mathrm{H}^{+}\right]_{i}$ did not ever appear to remain stable at initial homeostatic levels but gradually and continuously rose over the course of many hours. Only the long-term changes in $\mathrm{pH}_{i}$ appeared to be associated with the delayed neuronal death observed during this time period. Each of these changes in $\left[\mathrm{H}^{+}\right]_{i}$ may reflect different intracellular events consequent to GLU receptor activation.

Intracellular acidification following GLU exposure was expected from hydrogen ion-sensitive microelectrode recordings of frog motoneurons (Enders et al., 1986) and from recently reported fluorescence measurements in hippocampal neurons (Koch and Barish, 1991; Irwin and Paul, 1992; Raley-Susman et al., 1992a). The postulated $\mathrm{H}^{+}$fluxes would be consistent with extracellularly recorded alkaline transients in other preparations. Stimulus-evoked external alkaline shifts, recorded in the molecular layer of the turtle cerebellum, are antagonized by 


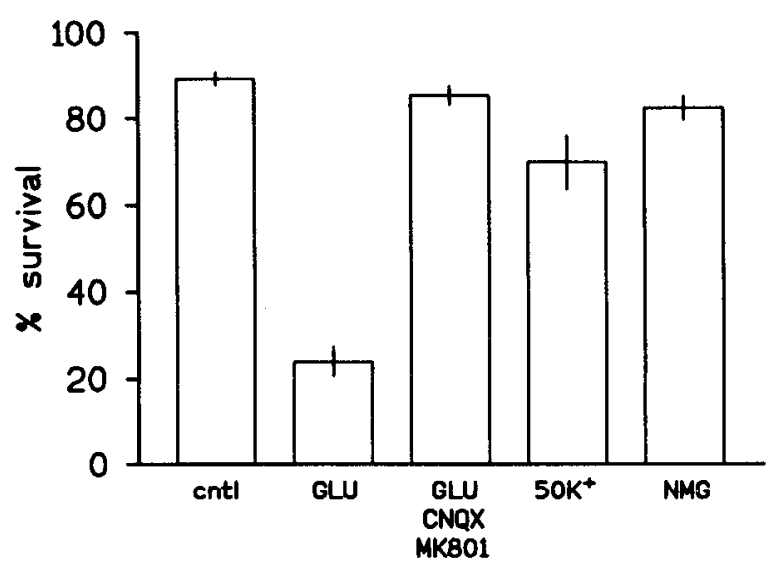

Figure 8. Survival of hippocampal neurons $24 \mathrm{hr}$ following a $5 \mathrm{~min}$ exposure to various treatments that altered $\mathrm{pH}_{i}$. Bars represent control solution changes (cntl), $500 \mu \mathrm{M}$ GLU $(G L U), 500 \mu \mathrm{M}$ GLU plus $20 \mu \mathrm{M}$ CNQX and $20 \mu \mathrm{M}$ MK-801 (GLU CNQX MK801), 50 mM external $\mathrm{K}^{+}$ $\left(50 K^{+}\right)$, and $\mathrm{NMG}^{+}$substitution for external $\mathrm{Na}^{+}(N M G)$. Data are combined from 12 fields in two experiments.

kynurenate and mimicked by GLU iontophoresis (Chesler and Chan, 1988; Chen and Chesler, 1991; Chesler and Kaila, 1992). Similarly in hippocampal slices, stimulation of the Schaffer collaterals produces an alkaline shift in CAl extracellular space, sensitive to GLU antagonists (Chen and Chesler, 1992a,b). These external alkalinizations appear associated with postsynaptic receptor activation rather than neuronal firing (Chen and Chesler, 1992b; Chesler and Kaila, 1992).

Displacement of $\mathrm{H}^{+}$from internal binding sites by the GLUinduced increase in cytosolic $\mathrm{Ca}^{2+}$ constitutes a likely explanation for the initial GLU-induced accumulation of $\mathrm{H}^{+}$. Direct injection of $\mathrm{Ca}^{2+}$ into snail neurons and Myxicola axoplasm leads to an increased $\left[\mathrm{H}^{+}\right]_{i}$ (Meech and Thomas, 1977; Abercrombie and Hart, 1986). Conversely, acidification of molluscan neurons, Myxicola axoplasm, neuroblastoma cells, and PC12 cells causes a concomitant increase in $\left[\mathrm{Ca}^{2+}\right]_{i}$ (Ahmed and Connor, 1980; Abercrombie and Hart, 1986; Dickens et al., 1989). Under experimental conditions comparable to those producing the increased $\left[\mathrm{H}^{+}\right]_{i}$ reported here, GLU produced rapid elevations in $\left[\mathrm{Ca}^{2+}\right]_{i}$, persisting for about an hour (Dubinsky, 1993b). The abundance of free calcium ions would have maintained the hydrogen ion displacement and prevented repeated GLU-induced acidifications. Two hours after GLU exposure, with calcium homeostasis reestablished and $\left[\mathrm{H}^{+}\right]_{i}$ near the normal range though not stable, a second GLU exposure could again produce increases in both $\left[\mathrm{Ca}^{2+}\right]_{i}$ and $\left[\mathrm{H}^{+}\right]_{i}$. Many hours after GLU exposure, the elevated $\left[\mathrm{H}^{+}\right]_{i}$ would largely prevent GLU-induced $\mathrm{Ca}^{2+}$ influx from further displacing bound $\mathrm{H}^{+}$. Elevated external $\mathrm{K}^{+}$, which should depolarize neurons to approximately $-27 \mathrm{mV}$, activate voltage-gated calcium channels, and cause an increase in $\left[\mathrm{Ca}^{2+}\right]_{i}$, produced a similar acidification, consistent with this displacement mechanism.

An initial acidification produced by $\mathrm{Ca}^{2+}$ displacement of $\mathrm{H}^{+}$ from internal binding sites could also possibly explain the inability of ionotropic GLU antagonists to prevent the increase in $\left[\mathrm{H}^{+}\right]_{i}$. Activation of unblocked metabotropic receptors causes a transient increase in $\left[\mathrm{Ca}^{2+}\right]_{i}$ that recovers to a plateau level (Furuya et al., 1989; Murphy and Miller, 1989; Dubinsky, 1993b). The release of calcium from internal stores could similarly displace bound hydrogen and transiently acidify hippocampal neu- rons. However, MK-801 alone can prevent GLU-induced increases in $\left[\mathrm{Ca}^{2+}\right]_{i}$ measured with fura-2 (Dubinsky and Rothman, 1991) and combined CNQX and MK-801 together prevented rises in $\left[\mathrm{Ca}^{2+}\right]_{i}$ with GLU applications identical to those employed here (Z. Hartley and J. M. Dubinsky, unpublished observations). Therefore, an additional GLU-induced process may contribute to the rapid acidification, independent of ionotropic receptor activation or changes in intracellular calcium.

Other explanations for the initial alterations in $\mathrm{pH}_{i}$ appear less satisfactory. Involvement of the $\mathrm{Na}^{+}-\mathrm{H}^{+}$antiporter can be ruled out since GLU persisted in acidifying neurons even when the antiporter was blocked by harmaline. The increased ATP hydrolysis required to reestablish calcium homeostasis might produce an overabundance of $\mathrm{H}^{+}$. However, this would not account for the absence of a second response at short intervals or the secondary alkalinization.

One often suggested possibility involves hydrogen ions entering neurons directly either through GLU channels, hydrogen ion channels, or other voltage-activated channels (Thomas and Meech, 1982; Mozhayeva and Naumov, 1983; Barish and Baud, 1984; Byerly et al., 1984; Chesler and Chan, 1988). Yet very little inward current has becn obscrved through $\mathrm{H}^{+}$channels (Barish and Baud, 1984; Byerly et al., 1984; Decoursey, 1991). $\mathrm{H}^{+}$influx through other channel types may also be insufficient for the following reasons. At rest the $\mathrm{H}^{+}$equilibrium potential is $-18 \mathrm{mV}$. If an ohmic conductance pathway were opened by GLU or GLU-induced depolarization, $\mathrm{H}^{+}$flux would initially be inward and could contribute to intracellular acidification. As $V_{m}^{r}$ approached $-10 \mathrm{mV}$, as demonstrated in hippocampal cultures (Rothman et al., 1987), the hydrogen influx would decrease rapidly and reverse direction. If enough $\mathrm{H}^{+}$entered in the initial milliseconds of GLU exposure to increase $\left[\mathrm{H}^{+}\right]_{i}$ measurably, then the $\mathrm{H}^{+}$equilibrium potential would become more negative and the hydrogen flux would reverse direction sooner. Thus, only a very rapid initial acid transient might accompany GLU application. Constant depolarization in the continued presence of GLU would promote $\mathrm{H}^{+}$efflux rather than the observed continual acidification over the course of several minutes. Therefore, $\mathrm{H}^{+}$influx via channel activation may not be sufficient to explain the observed initial acidification. The slow time course of acidification itself argues against a channel-mediated process. Additionally, the absence of a second GLU-induced increase in $\left[\mathrm{H}^{+}\right]_{i} 0.5 \mathrm{hr}$ following GLU pretreatment makes a channelspecific route of entry less probable.

Subsequent to the initial acidification, $\mathrm{pH}_{i}$ began to recover, in many neurons even before removal of the GLU. The recovery process probably reflected operation of exchange mechanisms for removal of the excess free cytoplasmic $\mathrm{H}^{+}$. Two different transport processes have been identified in hippocampal neurons recovering from an $\mathrm{NH}_{4} \mathrm{Cl}$-induced acid load: a DIDSsensitive $\mathrm{HCO}_{3}{ }^{-}$-dependent acid extruder, and an amilorideinsensitive, harmaline-sensitive $\mathrm{Na}^{+}-\mathrm{H}^{+}$antiporter (Raley-Susman et al., 1991). Similar exchange mechanisms have been charactcrized in sympathetic neurons, synaptosomes, and leech neurons (Deitmer and Schlue, 1987; Tolkovsky and Richards, 1987; Nachshen and Drapeau, 1988). In agreement with this previous work, DIDS, harmaline, and removal of external sodium reduced the rate of recovery from GLU-induced acid loads among hippocampal cells. DIDS had no apparent effect upon resting $\mathrm{pH}_{i}$ levels while harmaline produced a decrease in $\mathrm{pH}_{i}$. Thus, as previously reported, the $\mathrm{Na}^{+}-\mathrm{H}^{+}$antiporter was active at rest and in response to perturbations in $\mathrm{pH}_{i}$, while the $\mathrm{HCO}_{3}^{-}-$ 
dependent extrusion mechanism was only activated after intracellular acidification (Raley-Susman et al., 1991). The recovery processes were activated irrespective of the method of acid loading: $\mathrm{GLU}$, high $\mathrm{K}^{+}$, or external $\mathrm{Na}^{+}$removal.

Accompanying the recovery from acid loading was the rebound alkalinization and overshooting of the initial basal $\mathrm{pH}$ levels. Increasing $\left[\mathrm{H}^{+}\right]_{i}$ shifts the $\mathrm{pH}$ dependence of $\mathrm{Na}^{+}-\mathrm{H}^{+}$ antiporter operation to higher $\mathrm{pH}$ levels (Aronson et al., 1982; Grinstein et al., 1984). Activation of an internal allosteric modifier site on the $\mathrm{Na}^{+}-\mathrm{H}^{+}$antiporter by $\left[\mathrm{H}^{+}\right]_{i}$ increases the level to which $\mathrm{pH}_{i}$ must rise before the exchanger turns off (Moolenaar, 1986). Phosphorylation of a serine residue on the cytoplasmic domain of the transporter may also produce an alkaline shift in $\mathrm{pH}_{i}$ dependence of transporter function (Grinstein et al., 1992; Wakabayashi et al., 1992). The average alkaline $\mathrm{pH}_{i}$ attained in the experiments reported here ranged from 7.77 (17 $\left.\mathrm{nM}\left[\mathrm{H}^{+}\right]_{i}\right)$ at the end of the $60 \mathrm{~min}$ initial observation period (Fig. $1 A$ ) to $7.15\left(71 \mathrm{nM}\left[\mathrm{H}^{+}\right]_{i}\right)$ in freshly loaded neurons $0.5 \mathrm{hr}$ after GLU exposure (Fig. 5). These values are in the range of previously reported $\mathrm{pH}$ levels from other tissues (7.4-7.5, Grinstein and Rothstein, 1986). Manipulations effecting $\left[\mathrm{Ca}^{2+}\right]_{i}$ did not consistently alter the steady state rate of recovery from acidification (Table 1), in agreement with the absence of direct regulation of the $\mathrm{Na}^{+}-\mathrm{H}^{+}$antiporter by internal calcium (Grinstein et al., 1985b).

After attaining the slightly alkalinc $\mathrm{pH}_{i}$ lcvels, $\left[\mathrm{H}^{+}\right]_{i}$ in GLUexposed neurons began to return to initial basal levels. The gradual removal of $\mathrm{H}^{+}$from the internal regulatory site on the $\mathrm{Na}^{+}-\mathrm{H}^{+}$antiporter should restore the original $\left[\mathrm{H}^{+}\right]_{i}$. However, $\left[\mathrm{H}^{+}\right]_{i}$ homeostasis was not restored and $\left[\mathrm{H}^{+}\right]_{i}$ continued to climb gradually over the course of hours. The cumulative increase in $\left[\mathrm{H}^{+}\right]_{i}$ may reflect an increase in glycolytic metabolism and lactate production or a decline in cellular ability to buffer $\mathrm{H}^{+}$. The $\mathrm{Na}^{+}-\mathrm{H}^{+}$antiporter remained functional in this time period since an additional GLU challenge produced the characteristic secondary rebound recovery. The rate at which the transporter was able to extrude $\mathrm{H}^{+}$was, however, reduced in the hours following GLU pretreatment, since recovery from an additional GLUinduced acid load was slower than in nonpretreated cultures (Table 1). Since hydrogen effluxes increase with increasing acidity (Grinstein and Rothstein, 1986), the decline in recovery rate cannot be attributablc to the lowered $\mathrm{pH}_{i}$ at these extended times.

Operation of the $\mathrm{Na}^{+}-\mathrm{H}^{+}$antiporter depends upon the $\mathrm{Na}$ gradient but metabolic energy may contribute to its pumping ability and modulation by $\left[\mathrm{H}^{+}\right]_{i}$ (Cassel et al., 1986; Grinstein and Rothstein, 1986; Weissberg et al., 1989; Wakabayashi et al., 1992). With reduction of cellular ATP, the exchanger decreases its affinity for hydrogen at the internal regulatory site (Cassel et al., 1986; Wakabayashi et al., 1992). Therefore, the decline in overall neuronal metabolism several hours after GLU exposure (Raley-Susman et al., 1992b) would indirectly contribute to the observed reduction of antiporter activity. If $\mathrm{Na}$ / K-ATPase activity were compromised, a decline in the Na gradient, and hence rate of hydrogen removal, might be expected. Indeed, following anoxic exposure in hippocampal slices, intracellular potassium concentrations fall and sodium concentrations rise, consistent with a metabolic decrcasc in $\mathrm{Na} / \mathrm{K}$-ATPase activity (Kass and Lipton, 1982).

Alternatively, the decline in $\mathrm{Na}^{+}-\mathrm{H}^{+}$antiporter activity may be attributable to dephosphorylation of an internal regulatory site or regulatory protein. Indirect evidence suggests that protein kinase $\mathrm{C}$ may stimulate the antiporter via a phosphorylationdependent regulatory site in neuroblastoma cells and lymphocytes (Moolenaar et al., 1984; Grinstein et al., 1985a). Regulatory phosphorylation sites have also been implicated by antiporter sensitivity to calmodulin antagonists in cardiac ventriculocytes (Weissberg et al., 1989). With the loss of highenergy phosphate sources that accompanies excitotoxic damage (Kass and Lipton, 1982; Rothman et al., 1987), this regulatory site may become dephosphorylated, resulting in a slower rate of hydrogen extrusion. If the antiporter became unable to keep up with the normal hydrogen influx, a gradual intracellular acidification could ensue.

\section{$p H_{\mathrm{i}}$ and excitotoxicity}

The observed changes in $\left[\mathrm{H}^{+}\right]_{i}$ could contribute to excitotoxic injury in several ways. The initial increase in $\left[\mathrm{H}^{+}\right]_{i}$ and/or the hour or so of elevated $\left[\mathrm{OH}^{-}\right]$could initiate intracellular production of free radical species, leading to eventual neuronal death (Kogure et al., 1985; Monyer et al., 1990; Agardh et al., 1991). Since internal acidification of synaptosomes results in calcium-independent release of neurotransmitter (Drapeau and Nachshen, 1988), it is possible that GLU could be released from synaptic pools during this transient decrease in $\mathrm{pH}_{i}$, further compounding excitotoxic damage.

However, the acidification was not prolonged nor was the secondary alkalinization extensive. Moreover, similar initial perturbations produced by high potassium or sodium replacement were not toxic. During ischemia, brain $\mathrm{pH}_{i}$ falls rapidly and is followed by a secondary alkalosis during reperfusion (von Hanwehr et al., 1986; Silver and Erecinska, 1992). Anoxic brain slices similarly exhibited immediate acidification followed by rebound alkalinization (Pirttila and Kauppinen, 1992). In both in vivo and in vitro ischemic models, recovery of $\mathrm{pH}_{i}$ was notably slow (Pirttila and Kauppinen, 1992; Silver and Erecinska, 1992). Prolonged intracellular acidification has been demonstrated to cause neuronal death, in the absence of GLU exposure (Tombaugh and Sapolsky, 1990; Nedergaard et al., 1991). While the absolute levels of $\mathrm{H}^{+}$accumulation reported here were less than those previously reported to be toxic, they were recorded from neurons still surviving at prolonged times after GLU exposure. The $\left[\mathrm{H}^{+}\right]_{i}$ achieved in hippocampal neurons at the time of death may be even greater.

Excitotoxic neuronal death is generally thought to be mediated by the influx of calcium during excitatory amino acid overstimulation (Choi, 1990). The rise in $\left[\mathrm{Ca}^{2+}\right]_{i}$ persists for about an hour after an insult comparable to that used in the present experiments. Yet calcium homeostasis is restored and remains stable in neurons surviving hours after the insult (Randall and Thayer, 1992; Dubinsky, 1993b). In contrast, $\left[\mathrm{H}^{+}\right]_{i}$ homcostasis appears to be permanently disrupted following toxic insult. Cellular damage or death could result at any time from abnormal $\mathrm{pH}_{i}$ regulation. Indeed, the progressive increase in $\left[\mathrm{H}^{+}\right]_{i}$ in the hours following an excitotoxic insult may act synergistically with other calcium-mediated processes to potentiate neuronal death.

\section{References}

Abercrombie RF, Hart CE (1986) Calcium and proton buffering and diffusion in isolated cytoplasm from Myxicola axons. Am J Physiol 250:C391-C405.

Agardh CD, Zhang H, Smith M-L, Siesjo BK (1991) Free radical production and ischemic brain damage influence of postischemic oxygen tension. Int J Dev Neurosci 9:127-138.

Ahmed Z, Connor JA (1980) Intracellular pH changes induced by 
calcium influx during electrical activity in molluscan neurons. J Gen Physiol 75:403-426.

Aronson PS, Bounds SE (1980) Harmaline inhibition of Na-dependent transport in renal microvillus membrane vesicles. Am J Physiol 238: F210-F217.

Aronson PS, Nee J, Suhm MA (1982) Modifier role of internal $\mathrm{H}^{+}$in activating the $\mathrm{Na}^{+} / \mathrm{H}^{+}$exchanger in renal microvillus membrane vesicles. Nature 299:161-163.

Balkovetz DF, Leibach FH, Mahesh VB, Devoe LD, Cragoe EJ Jr, Ganapathy V (1986) $\mathrm{Na}^{+}-\mathrm{H}^{+}$exchanger of human placental brush border membrane: identification and characterization. Am J Physiol 251:C852-C860.

Barish ME, Baud C (1984) A voltage-gated hydrogen ion current in the oocyte membrane of the axolotl, Ambystoma. J Physiol (Lond) 352:243-263.

Boron WF, McCormick WC, Roos A (1981) $\mathrm{pH}$ regulation in barnacle muscle fibers: dependence on extracellular sodium and bicarbonate. Am J Physiol 240:C80-C89.

Byerly L, Meech R, Moody W Jr (1984) Rapidly activating hydrogen ion currents in perfused neurones of the snail, Lymnaea stagnalis. $\mathrm{J}$ Physiol (Lond) 351:199-216.

Cassel D, Katz M, Rotman M (1986) Depletion of cellular ATP inhibits $\mathrm{Na}^{+} / \mathrm{H}^{+}$antiport in cultured human cells. J Biol Chem 261: $5460-5466$.

Chen JCT, Chesler M (1991) Extracellular alkalinization evoked by GABA and its relationship to activity-dependent $\mathrm{pH}$ shifts in turtle cerebellum. J Physiol (Lond) 442:431-446.

Chen JCT, Chesler M (1992a) Modulation of extracellular pH by glutamate and GABA in rat hippocampal slices. J Neurophysiol 67 : 29-36.

Chen JCT, Chesler M (1992b) Extracellular alkaline shifts in rat hippocampal slice are mediated by NMDA and non-NMDA receptors. J Neurophysiol 68:342-344.

Chesler M, Chan CY (1988) Stimulus-induced extracellular pH transients in the in vitro turtle cerebellum. Neuroscience 27:941-948.

Chesler M, Kaila K (1992) Modulation of pH by neuronal activity. Trends Neurosci 15:396-402.

Chesler M, Rice ME (1991) Extracellular alkaline-acid pH shifts evoked by iontophoresis of glutamate and aspartate in turtle cerebellum. Neuroscience 41:257-267.

Choi DW (1990) Cerebral hypoxia: some new approaches and unanswered questions. J Neurosci 10:2493-2501.

Choi DW, Maulucci-Gedde M, Kriegstein AR (1987) Glutamate neurotoxicity in cortical cell culture. J Neurosci 7:357-368.

Ciardo A, Meldolesi J (1991) Regulation of intracellular calcium in cerebellar granule neurons: effects of depolarization and of glutamatergic and cholinergic stimulation. J Neurochem 56:184-191.

Connor JA, Wadman WJ, Hockberger E, Wong RKS (1988) Sustained dendritic gradients of $\mathrm{Ca}^{2+}$ induced by excitatory amino acids in CA 1 hippocampal neurons. Science 240:649-653.

Decoursey TE (1991) Hydrogen ion currents in rat alveolar epithelial cells. Biophys J 60:1243-1253.

De Erausquin GA, Manev H, Guidotti A, Costa E, Brooker G (1990) Gangliosides normalize distorted single-cell intracellular free $\mathrm{Ca}^{2+}$ dynamics after toxic doses of glutamate in cerebellar granule cells. Proc Natl Acad Sci USA 87:8017-8021.

Deitmer JW, Schlue WR (1987) The regulation of intracellular $\mathrm{pH}$ by identified glial cells and neurons in the central nervous system of the leech. J Physiol (Lond) 388:261-283.

Dickens CJ, Gillespie JI, Greenwell JR (1989) Interactions between intracellular $\mathrm{pH}$ and calcium in single mouse neuroblastoma (N2A) and rat pheochromocytoma cells (PC12). Q J Exp Physiol 74:671679 .

Drapeau P, Nachshen DA (1988) Effects of lowering extracellular and cytosolic $\mathrm{pH}$ on calcium fluxes, cytosolic calcium levels, and transmitter relcasc in presynaptic nerve terminals isolated from rat brain. J Gen Physiol 91:305-315.

Dubinsky JM (1989) Development of inhibitory synapses among striatal neurons in vitro. J Neurosci 9:3955-3965.

Dubinsky JM (1993a) Effects of calcium chelators on intracellular calcium and excitotoxicity. Neurosci Lett 150:129-132.

Dubinsky JM (1993b) Intracellular calcium levels during the period of delayed excitotoxicity. J Neurosci 13:623-631.

Dubinsky JM, Rothman SM (1991) Intracellular calcium concentrations during "chemical hypoxia" and excitotoxic neuronal injury. J Neurosci 11:2545-2551.
Enders W, Ballanyi K, Serve G, Grafe P (1986) Excitatory amino acids and intracellular $\mathrm{pH}$ in motoneurons of the isolated frog spinal cord. Neurosci Lett 72:54-58.

Furuya S, Ohmori H, Shigemoto T, Sugiyama H (1989) Intracellular calcium mobilization triggered by a glutamate receptor in rat cultured hippocampal cells. J Physiol (Lond) 414:539-548.

Gilbertson TA, Scobey R, Wilson M (1991) Permeation of calcium ions through non-NMDA glutamate channels in retinal bipolar cells. Science 251:1613-1615.

Glaum SR, Scholz WK, Miller RJ (1990) Acute- and long-term glutamate-mediated regulation of $\left[\mathrm{Ca}^{++}\right]_{i}$ in rat hippocampal pyramidal neurons in vitro. J Pharmacol Exp Ther 253:1293-1302.

Grinstein S, Rothstein A (1986) Mechanism of regulation of the Na'/ $\mathrm{H}^{+}$exchanger. J Membr Biol 90:1-12.

Grinstein S, Goetz JD, Rothstein A (1984) 22Na fluxes in thymic lymphocytes. II. Amiloride-sensitive $\mathrm{Na} / \mathrm{H}$ exchange pathway; reversibility of transport and asymmetry of the modifier site. J Gen Physiol 84:585-600.

Grinstein S, Cohen S, Goetz JD, Rothstein A (1985a) Osmotic and phorbol ester-induced activation of $\mathrm{Na}^{+} / \mathrm{H}^{+}$exchange: possible role of protein phosphorylation in lymphocyte volume regulation. J Cell Biol 101:269-276.

Grinstein S, Rothstein A, Cohen S (1985b) Mechanism of osmotic activation of $\mathrm{Na}^{+} / \mathrm{H}^{+}$exchange in rat thymic lymphocytes. J Gen Physiol 85:765-787.

Grinstein S, Woodside M, Sardet C, Pouyssegur J, Rotin D (1992) Activation of the $\mathrm{Na}{ }^{1} / \mathrm{H}^{1}$ antiporter during cell volume regulation. Evidence for a phosphorylation-independent mechanism. J Biol Chem 267:23823-23828.

lino M, Ozawa S, Tsuzuki K (1990) Permeation of calcium through excitatory amino acid receptor channels in cultured rat hippocampal neurones. J Physiol (Lond) 424:151-165.

Irwin RP, Paul SM (1992). Glutamate exposure rapidly decreases intracellular $\mathrm{pH}$ in rat hippocampal neurons in culture. Soc Neurosci Ahstr 18:257.

James-Kracke MR (1992) Quick and accurate method to convert $\mathrm{BCECF}$ fluorescence to $\mathrm{pH}_{\mathrm{i}}$ : calibration in three different types of cell preparations. J Cell Physiol 151:596-603.

Jarolimek W, Misgeld U, Lux HD (1989) Activity dependent alkaline and acid transients in guinea pig hippocampal slices. Brain Res 505: 225-232.

Kaila K, Paalasma P, Taira T, Voipio J (1992) $\mathrm{pH}$ transients due to monosynaptic activation of $\mathrm{GABA}_{\mathrm{A}}$ receptors in rat hippocampal slices. Neuroreport 3:105-108.

Kass IS, Lipton P (1982) Mechanisms involved in irreversible anoxic damage to the in vitro rat hippocampal slice. J Physiol (Lond) 332: $459-472$.

Katsura K, Ekholm A, Asplund B, Siesjo BK (1991) Extracellular pH in the brain during ischemia: relationship to the severity of lactic acidosis. J Cereb Blood Flow Metab 11:597-599.

Koch RA, Barish ME (1991) Sodium-calcium exchange in cultured embryonic mouse hippocampal neurons. J Cell Biol 115:22a.

Kogure K, Arai H, Abe K, Nakano M (1985) Free radical damage of the brain following ischemia. Prog Brain Res 63:237-259.

Kraig RP, Chesler M (1990) Astrocytic acidosis in hyperglycemic and complete ischemia. J Cereb Blood Flow Metab 10:104-114.

Kraig RP, Pulsinelli WA, Plum F (1986) Carbonic acid buffer changes during complete brain ischemia. Am J Physiol 250:R348-R357.

MacDermott AB, Dale N (1987) Receptors, ion channels and synaptic potentials underlying the in tegrative actions of excitatory amino acids. Trends Neurosci 10:280-284.

Manev H, Favaron M, Guidotti A, Costa E (1989) Delayed increase of $\mathrm{Ca}^{2+}$ influx elicited by glutamate: role in neuronal death. Mol Pharmacol 36:106-112.

Meech RW, Thomas RC (1977) The effect of calcium injection on the intraccllular sodium and $\mathrm{pH}$ of snail ncurones. J Physiol (Lond) 265: 867-879.

Michaels RL, Rothman SM (1990) Glutamate neurotoxicity in vitro: antagonist pharmacology and intracellular calcium concentrations. $\mathrm{J}$ Neurosci 10:283-292.

Monyer H, Hartley M. Choi DW (1990) 21-Aminosteroids attenuate excitotoxic neuronal injury in cortical cell cultures. Neuron $5: 121$ 126.

Moolenaar WH (1986) Effects of growth factors on intracellular pH regulation. Annu Rev Physiol 48:363-376.

Moolenaar WH, Tsien RY, van der Saag PT, de Laat SW (1984) $\mathrm{Na}^{+} /$ 
$\mathrm{H}^{+}$exchange and cytoplasmic $\mathrm{pH}$ in the action of growth factors in human fibroblasts. Nature 304:645-648.

Mozhayeva GN, Naumov AP (1983) The permeability of sodium channels to hydrogen ions in nerve fibres. Pfluegers Arch 396:163173.

Murphy SN, Miller RJ (1989) Two distinct quisqualate receptors regulate $\mathrm{Ca}^{2+}$ homeostasis in hippocampal neurons in vitro. Mol Pharmacol 35:671-680.

Murphy SN, Thayer SA, Miller RJ (1987) The effects of excitatory amino acids on intracellular calcium in single mouse striatal neurons in vitro. J Neurosci 7:4145-4158.

Nachshen DA, Drapeau P (1988) The regulation of cytosolic $\mathrm{pH}$ in isolated presynaptic nerve terminals from rat brain. J Gen Physiol 91:289-303.

Nedergaard M, Goldman SA, Desai S, Pulsinelli WA (1991) Acidinduced death in neurons and glia. J Neurosci 11:2489-2497.

Ogura A, Miyamato M, Kudo Y (1988) Neuronal death in vitro: parallelism between survivability of hippocampal neurons and sustained elevation of cytosolic $\mathrm{Ca}^{2+}$ after exposure to glutamate receptor agonist. Exp Brain Res 73:447-458.

Orrenius S, McConkey DJ, Jones DP, Nicotera P (1988) $\mathrm{Ca}^{2+}$-activated mechanisms in toxicity and programmed cell death. ISI Atlas Sci 319-324.

Pirttila TRM, Kauppinen RA (1992) Recovery of intracellular pH in cortical brain slices following anoxia studied by nuclear magnetic resonance spectroscopy: role of lactate removal, cxtraccllular sodium and sodium/hydrogen exchange. Neuroscience 47:155-164.

Raley-Susman KM, Cragoe EJ Jr, Sapolsky RM, Kopito RR (1991) Regulation of intracellular $\mathrm{pH}$ in cultured hippocampal neurons by an amiloride-insensitive $\mathrm{Na}^{+} / \mathrm{H}^{+}$exchanger. J Biol Chem 266:27392745 .

Raley-Susman KM, Kopito RR, Sapolsky RM (1992a) NMDA exposure reduces intracellular $\mathrm{pH}$ in cultured hippocampal neurons. Soc Neurosci Abstr 18:803.

Raley-Susman KM, Miller KR, Owicki JC, Sapolsky RM (1992b) Effects of excitotoxin exposure on metabolic rate of primary hippocampal cultures: application of silicon microphysiometry to neurobiology. J Neurosci 12:773-780.

Randall RD, Thayer SA (1992) Glutamate-induced calcium transient triggers delayed calcium overload and ncurotoxicity in rat hippocampal neurons. J Neurosci 12:1882-1895.
Rothman SM, Thurston JH, Hauhart RE (1987) Delayed neurotoxicity of excitatory amino acids in vitro. Neuroscience 22:471-480.

Siesjo BK (1992) Pathophysiology and treatment of focal cerebral ischemia. II. Mechanisms of damage and treatment. J Neurosurg 77: 337-354.

Silver IA, Erecinska M (1992) Ion homeostasis in rat brain in vivo: intra- and extracellular $\left[\mathrm{Ca}^{2+}\right]$ and $\left[\mathrm{H}^{+}\right]$in the hippocampus during recovery from short-term, transient ischemia. J Cereb Blood Flow Metab 12:759-772.

Thomas JA, Buchsbaum RN, Zimniak A, Racker E (1979) Intracellular pH measurements in Ehrlich ascites tumor cells utilizing spectroscopic probes generated in situ. Biochemistry 18:2210-2218.

Thomas RC, Meech RW (1982) Hydrogen ion currents and intracellular $\mathrm{pH}$ in depolarized voltage-clamped snail neurones. Nature 299: 826-828.

Tolkovsky AM, Richards CD (1987) $\mathrm{Na}^{+} / \mathrm{Ca}^{++}$exchange is the major mechanism of $\mathrm{pH}$ regulation in cultured sympathetic neurons: measurements in single cell bodies and neurites using a fluorescent $\mathrm{pH}$ indicator. Neuroscience 22:1093-1 102.

Tombaugh GC, Sapolsky RM (1990) Mechanistic distinctions between excitotoxic and acidotic hippocampal damage in an in vitro model of ischemia. J Cereb Blood Flow Metab 10:527-535.

von Hanwehr R, Smith MJ, Siesjo BK (1986) Extra- and intracellular $\mathrm{pH}$ during near-complete forebrain ischemia in the rat. J Neurochem 46:331-339

Wahl P, Schousboc A, Honore T, Drcjer J (1989) Glutamatc-induced increase in intracellular $\mathrm{Ca}^{2+}$ in cerebral cortex neurons is transient in immature cells but permanent in mature cells. $J$ Neurochem 53: 1316-1319.

Wakabayashi S, Sardet C, Fafournoux P, Counillon L, Meloche S, Pages G, Pouyssegur J (1992) Structure function of the growth factoractivatable $\mathrm{Na}^{+} / \mathrm{H}^{+}$exchanger (NHE1). Rev Physiol Biochem Pharmacol 119:157-186.

Weissberg PL, Little PJ, Cragoe EJ Jr, Bobik A (1989) The pH of spontaneously beating cultured rat heart cells is regulated by an ATPcalmodulin-dependent $\mathrm{Na}^{+} / \mathrm{H}^{+}$antiport. Circ Res 64:676-685.

Yamada KA, Dubinsky JM, Rothman SM (1989) Quantitative physiological characterization of a quinoxalinedione non-NMDA receptor antagonist. J Neurosci 9:3230-3236. 